\title{
Evaluasi Dalam Pembelajaran Penjasorkes Di SMP Negeri Se-Kecamatan Beliyu
}

\author{
Ahmad Andika ${ }^{1}$, Dessy Wardiah ${ }^{2}$, Daryono $^{3}$ \\ Program Studi Pendidikan Jasmani, Fakultas Keguruan dan Ilmu Pendidikan Universitas PGRI \\ Palembang \\ email : windimariza123@gmail.com
}

\begin{abstract}
Abstrak. Masalah dalam penelitian ini adalah belum diketahui seberapa baik pelaksanaan pembelajaran khususnya pembelajaran Penjasorkes di SMP Negeri se-Kecamatan Belinyu. Metode penelitian menggunakan teknik survei dengan menggunakan kuesioner atau angket. Informan yang digunakan berjumlah 8 orang dari 4 sekolah SMP Negeri se-Kecamatan Belinyu. Pengumpulan data menggunakan kuesioner atau angket. Analisis data menggunakan analisis deskriptif persentase. Dari hasil penelitian dapat disimpulkan bahwa evaluasi pembelajaran di SMP Negeri se-Kecamatan Belinyu sudah dilaksanakan dengan sangat baik dengan persentase 83,57\%. Hasil penelitian berdasarkan pelaksanaan evaluasi di tiap-tiap sekolah diperoleh hasil yaitu pelaksanaan evaluasi di SMP Negeri 1 Belinyu sudah dilaksanakan dengan sangat baik dengan persentase 83,88\%, pelaksanaan evaluasi di SMP Negeri 2 Belinyu sudah dilaksanakan dengan sangat baik dengan persentase $87,5 \%$, pelaksanaan evaluasi di SMP Negeri 3 Belinyu sudah dilaksanakan dengan baik dengan persentase $73,75 \%$ dan pelaksanaan evaluasi di SMP Negeri 4 Belinyu sudah dilaksanakan dengan sangat baik dengan persentase $89,16 \%$.
\end{abstract}

Kata kunci : Evaluasi Pembelajaran Penjasorkes

Abstract. The problem in this research is that it is not yet known whether the implementation of learning, especially the Physical Education learning in SMP Negeri in Belinyu District. The research method uses a survey technique using a questionnaire or a questionnaire. The informants used in the bathroom were 8 people from 4 State Junior High Schools in Belinyu District. Data collection using a questionnaire or questionnaire. Data analysis used descriptive analysis of proportions. From the research results, it can be seen that the learning evaluation in SMP Negeri in Belinyu District has been implemented very well with a proportion of $83.57 \%$. The results of the study based on the evaluation of each student obtained by the evaluation results at SMP Negeri 1 Belinyu have been carried out very well with a proportion of $83.88 \%$, the implementation of the evaluation at SMP Negeri 2 Belinyu has been carried out very well with a proportion of $87.5 \%$, the implementation of the evaluation in SMP Negeri 3 Belinyu has been implemented well with the proportion of $73.75 \%$ and the implementation of evaluation at SMP Negeri 4 Belinyu has been carried out very well with a proportion of $89.16 \%$.

Key Words: Physical Education Learning Evaluation

\section{PENDAHULUAN}

Pendidikan Jasmani adalah proses pendidikan melalui penyediaan pengalaman belajar kepada siswa berupa aktivitas jasmani, bermain dan berolahraga yang direncanakan secara sistematik guna merangsang pertumbuhan dan perkembangan fisik, keterampilan motorik, keterampilan berpikir, emosional, sosial dan moral. Pendidikan jasmani merupakan hal yang memiliki peranan penting dalam perkembangan siswa dalam memberikan kesempatan kepada siswa untuk terlibat langsung dalam aneka pengalaman belajar melalui aktivitas jasmani, bermain dan aktivitas olahraga secara sistematis. Pembekalan pengalaman belajar itu diarahkan untuk membina, sekaligus membentuk gaya hidup sehat dan aktif sepanjang hayat. Hal tersebut merupakan media untuk mendorong perkembangan 
keterampilan motorik, kemampuan fisik, pengetahuan dan penalaran, penghayatan nilai-nilai (sikap, mental, emosional, spiritual dan sosial), serta pembiasaan pola hidup sehat yang bermuara untuk merangsang pertumbuhan dan perkembangan yang seimbang.

Menurut Depdiknas (2006: 131), Pendidikan Jasmani dan Olahraga merupakan satu mata ajar yang diberikan di suatu jenjang tertentu yang merupakan salah satu bagian dari pendidikan keseluruhan yang mengutamakan aktivitas jasmani dan pembinaan hidup sehat untuk bertumbuh dan perkembangan jasmanai, mental, sosial dan emosional yang serasi, selaras dan seimbang.

Pada umumnya tujuan Pendidikan Jasmani adalah menekankan aspek pendidikan bersifat menyeluruh (kesehatan, kebugaran jasmani, keterampilan berfikir kritis, stabilitas emosional, keterampilan sosial, penalaran dan tindakan moral). Atau secara spesifik melalui pembelajaran Pendidikan Jasmani, siswa melakukan kegiatan berupa permainan (game), dan berolahraga (disesuaikan dengan pertumbuhan dan perkembangan anak). Meskipun demikian unsur prestasi dan kompetensi juga terdapat di dalamnya dan dimanfaatkan sebagai alat pendidikan.

Tujuan pendidikan dari Pendidikan Jasmani yaitu untuk mengembangkan keterampilan-keterampilan gerak dan keterampilan berbagai macam permainan dan olahraga, memelihara kebugaran jasmani melalui aktivitas jasmani dan olahraga, mengetahui dan memahami konsep aktivitas jasmani dan olahraga sebagai informasi untuk mencapai kesehatan, kebugaran, dan pola hidup sehat, mengembangkan sikap sportif, jujur, disiplin, bertanggungjawab, kerjasama, percaya diri dan demokrasi melalui aktivitas jasmani, permainan dan olahraga.

Untuk mencapai tujuan tersebut, dalam proses pembelajaran Pendidikan Jasmani guru harus mengajarkan berbagai keterampilan gerak dasar, teknik dan strategi permainan/olahraga, internalisasi nilai-nilai (sportivitas, jujur, kerjasama dan lain-lain) serta pembiasaan-pembiasaan pola hidup sehat yang diminati setiap pembelajarannya, bukan melalui pengajaran yang konvensional di dalam kelas yang bersifat kajian teoritis. Aktivitas-aktivitas yang diberikan yang diberikandalam pengajaran harus mendapat sentuhan didaktik-metodik dari guru Pendidikan Jasmani sehingga aktivitas yang dilakukan dapat mencapai tujuan pengajaran.

Dalam mencapai tujuan pendidikan diperlukan evaluasi yang mendalam karena dengan evaluasi guru dapat mengetahui tingkat keberhasilan dalam hal ini siswa dalam mengikuti pembelajaran pendidikan jasmani yang telah diajarkan pendidik atau guru

Observasi dilakukan selama empat hari dari tanggal 3 Januari - 6 Januari 2020. Berdasarkan hasil observasi atau pengamatan yang dilakukan peneliti di empat SMP Negeri se-Kecamatan Belinyu, peneliti mendapati bahwa rata-rata ada beberapa guru Penjasorkes yang masih kurang memperhatikan pentingnya sebuah kegiatan evaluasi dalam setiap pembelajaran Penjasorkes. Padahal evaluasi sangatlah penting dalam setiap pembelajarannya untuk melihat perkembangan peserta didik. Evaluasi harus dilakukan secara kontinu dan sistematis sesuai-sesuai ketentuan dan pedoman dalam pelaksanaan kegiatan evaluasi pembelajaran Penjasorkes agar seorang guru dapat memperoleh gambaran tentang tingkat kemampuan dari setiap peserta didiknya.

Ada beberapa guru yang melaksanakan proses evaluasinya pada saat tertentu saja. Misalnya, guru melaksanakan evaluasi hanya pada saat unit akhir pelajaran saja, ada yang pertengahan pelajaran, ada yang melaksanakan evaluasinya saat akhir pengajaran dan ada bahkan guru lupa tidak melakukan evaluasi sama sekali dalam jam pelajarannya. Jadi kadang guru kurang memperoleh informasi tentang kesulitan peserta didiknya sehingga menyebabkan guru sering salah memprediksi dalam menilai kemampuan siswa di kelasnya. Terkadang guru hanya melihat hasil akhirnya saja tanpa melihat awal proses perkembangan dari setiap individu siswanya. Hal ini menunjukkan bahwa pelaksanaan evaluasi belum berjalan maksimal karena belum dilakukan pelaksanaan evaluasi secara menyeluruh. Ada 
juga sebagian guru yang tidak menggunakan silabus dan RPP sebagai pedomannya.

Seorang guru perlu memahami cara atau strategi evaluasi yang tepat untuk digunakan oleh seorang guru sebagai acuan atau pedomannya agar memperoleh informasi yang diperlukan tentang perkembangan peserta didiknya. Tugas guru dalam melaksanakan evaluasi untuk membantu perkembangan siswa dalam mencapai tujuan umum pendidikan yang telah ditetapkan pemerintah atau pihak yang terkait. Untuk mencapai tujuan tersebut, guru harus lebih aktif dalam meningkatkan evaluasi dalam setiap pembelajarannya.

\section{KAJIAN LITERATUR}

Evaluasi adalah proses yang sistematis, bersifat komprehensif yang meliputi pengukuran, penilaian, analisis dan intrepretasi informasi atau data untuk menentukan sejauh mana peserta didik telah mencapai tujuan pembelajaran yang dilakukan dengan tujuan untuk mengetahui tingkat keberhasilan sesuatu program pendidikan, pengajaran, ataupun pelatihan yang dilaksanakan. (Widiyanto, 2018: 9). Menurut Winarno (2014: 5) evaluasi merupakan suatu proses yang sistematis untuk menentukan nilai berdasarkan data yang dikumpulkan berdasarkan pengukuran. Pemberian nilai harus objektif dan diusahakan unsur-unsur subjektif tidak masuk sebagai pertimbangan dalam penilaian. Ralph W.Tyler (dalam Rosdiani 2015: 143) mengatakan bahwa evaluasi adalah usaha untuk memeriksa kesesuaian (congruence) antara tujuan-tujuan pendidian yang diinginkan dan hasil belajar yang dicapai.

Dalam buku Evaluasi Pembelajaran (Asrul, Ananda dan Rosnita, 2015: 12) Chittenden (1994) secara simpel mengklasifikasikan tujuan evaluasi adalah untuk keeping track, checking-up, finding-out, and summing-up. Keempat tujuan tersebut oleh Arifin (2013: 15) diuraikan sebagai berikut:

1. Keeping track, yaitu untuk menelusuri dan melacak proses belajar peserta didik sesuai dengan rencana pelaksanaan pembelajaran yang telah ditetapkan.
Untuk itu, guru harus mengumpulkan data dan informasi dalam kurun waktu tertentu melalui berbagai jenis dan teknik penilaian untuk memperoleh gambaran tentang pencapaian kemajuan belajar peserta didik.

2. Cheking-up, yaitu untuk mengecek ketercapaian kemampuan peserta didik dalam proses pembelajaran dan kekurangan-kekurangan peserta didik selama mengikuti proses pembelajaran. Dengan kata lain, guru perlu melakukan evaluasi untuk mengetahui bagian mana dari materi yang sudah dikuasai peserta didik dan bagian mana dari materi yang belum dikuasai.

3. Finding-out, yaitu untuk mencari, menemukan dan mendeteksi kekurangan kesalahan atau kelemahan pserta didik dalam proses pembelajaran, sehingga guru dapat dengan cepat mencari alternatif solusinya.

4. Summing-up, yaitu untuk menyimpulkan tingkat kemampuan peserta didik terhadap kompetensi yang telah ditetapkan. Hasil penyimpulan ini dapat digunakan guru untuk menyusun laporan kemajuan belajar ke berbagai pihak yang berkepentingan.

Menurut Widiyanto (2018: 17) dalam bukunya yang berjudul Evaluasi Pembelajaran fungsi evaluasi secara umum sebagai berikut:

a) Untuk mengetahui kemajuan belajar peserta didik. Melalui evaluasi yang dilakukan terhadap proses pembelajaran yang telah disampaikan di depan kelas.

b) Memberikan dorongan belajar bagi peserta didik. Bagi peserta didik yang memiliki prestasi belajar yang baik melalui tes yang dilakukan, dapat memberikan dorongan yang kuat untuk meningkatkan dan mempertahankan prestasi yang telah dicapainya.

c) Sebagai laporan bagi orang tua peserta didik. Hasil penilaian kemajuan belajar yang biasanya berbentuk Buku Raport sangat penting bagi orang tua peserta didik, sebagai bahan informasi mengenai kemajuan belajar yang dicapai anaknya. (Sakni, 2006) 
Menurut Ngatman (2017: 6-8) dalam pelaksanaan evaluasi dibedakan dua macam prinsip, yaitu: yang pertama, Prinsip-prinsip pelaksanaan, yaitu prinsip-prinsip yang perlu diikuti dalam melakukan atau mengadakan evaluasi.Adapun prinsi-prinsip pelaksanaan yang penting ialah:

1. Evaluasi harus dilaksanakan secara objektif. Yang dimaksud objektif disini ialah bahwa evaluasi itu harus berdasarkan bukti-bukti yang nyata. Tidak dapat dibenarkan memberikan evaluasi hanya berdasarkan ingatan saja.

2. Evaluasi harus dilakukan secara kontinu. Artinya harus diadakan evaluasi terhadap anak didik secara terus-menerus tanpa putus-putusnya. Tidak perlu menunggu sampai satu bulan atau lebih untuk melaksanakan suatu evaluasi. Lebih baik lagi setiap selesai pembelajaran selalu melaksanakan evaluasi.

3. Evaluasi hendakmya dilakukan secara komprensif. Artinya bahwa evaluasi itu sejauh mungkin harus menilai semua aspek dari keseluruhan kepribadian anak didik. Evaluasi terhadap anak didik harus mencakup hal-hal yang berhubungan dengan kemampuan dan pengetahuan dalam pelajaran Penjasorkes, kelakuannya, disiplinnya, sikap-sikap sosialnya kegiatannya dalam mengikuti pelajaran, kegiatannya dalam mengikuti aktivitas sosial baik di dalam maupun di luar sekolah.

Yang kedua,Prinsip-prinsip dasar, yaitu prinsip-prinsip yang harus dipegang sebagai pedomankerja dalam pelaksanaan evaluasi.Adapun prinsip-prinsip dasar yang penting sebagai pedoman kerja dalam melaksanakan evaluasi ialah:

1. Evaluasi adalah alat komunikasi. Komunikasi antar sekolah dengan sekolah, antara sekolah dengan orang tua, antara sekolah dengan masyarakat. Oleh karena itu, evaluasi merupakan alat komunikasi untuk berbagai pihak yang mempunyai arti meaningfull bagi semua pihak yang bersangkutan. Laporan hasil penilaian harus lebih terperinci dan meliputi seluruh segi.
2. Maksud utama dari evaluasi terhadap anak didik adalah membantu anak didik untuk mencapai perkembangan potensinya semaksimal mungkin. Ini tidak berarti bahwa yang diinginkan membuat anak didik menjadi pandai semua dan pandai dalam segala hal tanpa mengingat batas-batas pembawaan kemampuan setiap anak didik.

3. Dalam evaluasi anak didik harus dibimbing dengan dirinya sendiri, jangan dibandingkan dengan anak didik lainnya. Dengan dibandingkan dengan dirinya sendiri pendidikan akan mendapatkan gambaran yang jelas tentang kemajuan anak didiknya.

4. Dalam melaksanakan evaluasi, hendaknya memanfaatkan berbagai macam alat atau teknik evaluasi. Dengan demikian diperoleh gambaran atau kesimpulan yang lebih dapat dipercaya.

5. Evaluasi setidaknya menyarankan langkah-langakah atau tindakan lanjut yang perlu diambil, misalnya saran-saran dalam pemilihan jurusan pendidikan terhadap anak didik.

Ngatman (2017: 8-9) mengemukakan bahwa evaluasi sangat penting dalam pendidikan, perlu diusahakan pemahaman evaluasi yang mendalam agar dapat mencegah kemungkinan-kemungkinan kesalahan sekecil apapun dalam evaluasi. Adapun hal-hal yang mungkin terjadi kesalahan-kesalahan dalam mengevaluasi adalah:

1. Kesalahan dalam pengamatan atau observasi. Misalnya, observasi itu kurang dilakukan secara teliti. Observasi itu kurang menyeluruh terhadap aspekaspeknya. Baru satu atau dua kali melaksanakan evaluasi sudah langsung mengambil kesimpulan. Cara atau teknik seperti itu kurang tepat.

2. Kesalahan-kesalahan pada alat ukur, misalnya tes yang dipergunakan tidak memenuhi syarat-syarat pembuatan tes yang baik atau soal-soal yang dibuat oleh pendidik kurang memperhatikan petunjuk dalam penyusunannya.

3. Kesalahan-kesalahan dalam proses analisis data. Misalnya kesalahan dalam 
perhitungan atau penjumlahan dan sebagainya.

4. Pengaruh-pengaruh dari pekerjaan yang terdahulu, misalnya jika pekerjaan yang dulu baik, maka pendidik dipengaruhi untuk memberikan nilai yang baik juga atau sebaliknya.

5. Kecendrungan dari seorang pendidik untuk menilai lebih rendah atau lebih tinggi. Misalnya pendidik tersebut mempunyai kecendrungan memberikan nilai-nilai yang rendah seperti 4, 5, 6, 7 . Jarang sekali memberikan nilai 8. Begitu juga sebaliknya.

6. Pengaruh dari luar. Misalnya pakaian yang rapi dan bersih, tingkah laku yang sopan dan sebagainya. Ini juga mempengaruhi seorang pendidik dalam memberikan penilaian.

Menurut Widiyanto (2018: 1) kata dasar "pembelajaran" adalah belajar. Dalam arti sempit pembelajaran dapat diartikan sebagai suatu proses atau cara yang dilakukan agar seseorang dapat melakukan kegiatan belajar. Menurut Sugandi (2006: 9) menyebutkan bahwa Pembelajaran merupakan suatu kumpulan proses yang bersifat individual, yang mengubah stimuli dari lingkungan seseorang ke dalam sejumlah informasi, yang selanjutnya dapat menyebabkan adanya hasil belajar dalam bentuk ingatan jangka panjang.

Pendidikan Jasmani adalah proses pendidikan melalui penyediaan pengalaman belajar kepada siswa berupa aktivitas jasmani, bermain dan berolahraga yang direncanakan secara sistematik guna merangsang pertumbuhan dan perkembangan fisik, keterampilan motorik, keterampilan berpikir, emosional, sosial dan moral. Pendidikan jasmani merupakan hal yang memiliki peranan penting dalam perkembangan siswa dalam memberikan kesempatan kepada siswa untuk terlibat langsung dalam aneka pengalaman belajar melalui aktivitas jasmani, bermain dan aktivitas olahraga secara sistematis. (Rosdiani, 2015: 1)

\section{METODE PENELITIAN}

Metode penelitian adalah cara yang digunakan oleh peneliti dalam mengumpulkan datanya. Dalam penelitian ini, peneliti menggunakan metode survei. Dalam penelitian kualitatif, kualitas riset sangat bergantung pada kualitas dan kelengkapan data yang dihasilkan. Pertanyaan yang selalu diperhatikan dalam pengumpulan data adalah apa, siapa, dimana, kapan dan bagaimana. Penelitian dengan metode kualitatif bertumpu pada Triangulation data yang dihasilkan dari tiga mode : interview, participan to observation dan telaah catatan organisasi (document records).

Dalam penelitian kualitatif pengumpulan data lazimnya mengunakan metode yang bervariasi. Variasi metode yang dimaksud adalah angket, wawancara, pengamatan atau observasi, tes dan dokumentasi. Metode yang digunakan dalam penelitian ini adalah dengan menggunakan teknik angket atau kuesioner, observasi dan dokumentasi.

Pengumpulan data merupakan proses mengidentifikasi dan mengoleksi informasi yang dilakukan oleh peneliti, sesuai dengan tujuan penelitian. Teknik pengumpulan data dalam penelitian Penjasorkes dapat berupa: tes dan non-tes. Instrumen tes berupa teknik tes yang meliputi: tes keterampilan, tes tulis dan tes lisan. Sedangkan yang non-tes berupa: angket atau kuesioner, interviu atau wawancara, observasi, inventori dan dokumentasi. Dalam penelitian ini teknik pengumpulan data yang akan digunakan adalah teknik non-tes yaitu teknik observasi, angket atau kuesioner dan dokumentasi.(Winarno, 2013: 143-145)

Observasi merupakan teknik pengumpulan data dengan mengadakan pengamatan secara langsung terhadap suatu kejadian tertentu. Observasi dapat dilakukan dengan terencana maupun insidental, dapat dilakukan oleh siapa saja karena bentuknya yang sederhana. Agar observasi dapat dilakukan secara cermat dan kontinu sehingga diperoleh data yang seobjektif mungkin, maka diperlukan alat perekam data observasi yang mudah dan jelas untuk dilaksanakan seperti tape recorder, video, film dan sebagainya. (Winarno, 2004: 154)

Dalam menggunakan metode observasi cara yang paling efektif adalah melengkapinya dengan format atau blangko 
pengamatan sebagai instrumen. Format yang disusun berisi butir-butir tentang kejadian atau tingkah laku yang digambarkan akan terjadi. Dari peneliti berpengalaman diperoleh suatu petunjuk bahwa mencatat data observasi bukan hanya sekedar mencatat, tetapi juga mengadakan pertimbangan kemudian mengadakan penilaian kedalam suatu skala bertingkat.

Menurut Sugiyono (2018: 240) dokumentasi merupakan catatan peristiwa yang sudah berlalu. Dokumentasi bisa berbentuk tulisan, gambar, atau karya-karya monumental dari seseorang. Dokumentasi yang berbentuk tulisan misalnya catatan harian, sejarah kehidupan (life histories), ceritera, biografi, peraturan dan kebijakan. Dokumentasi yang berbentuk gambar misalnya foto, gambar hidup, sketsa dan lainlain. Dokumentasi yang berbentuk karya misalnya karya seni yang dapat berupa gambar, patung, film dan lain-lain. Studi dokumentasi merupakan pelengkap dari penggunaan metode observasi dan wawancara dalam penelitian kualitatif. Dalam penelitian ini, peneliti langsung mendokumentasi proses pelaksanaan evaluasi, pengisian angket dan hal lainnya yang mendukung penelitian dengan mengambil foto dan video saat pelaksanaan.

Menurut Sugiyono (2018:142) angket adalah teknik pengumpulan data yang dilakukan dengan cara memberi seperangkat pertanyaan atau pernyataan tertulis kepada responden untuk menjawabnya. Angket merupakan teknik pengumpulan yang efisien jika peneliti tahu dengan pasti variabel yang akan diukur dan tahu apa yang tidak diharapkan dari responden. Dalam penelitian ini, peneliti menggunakan empat pilihan jawaban untuk responden, yaitu selalu, sering, kadang -kadang dan tidak pernah untuk memperoleh sejauh mana proses evaluasi yang responden laksanakan dalam proses pembelajaran Penjasorkes.
Tabel 1. Pemberian skor dari tiap-tiap jawaban responden:

\begin{tabular}{|c|c|}
\hline ALTERNATIF JAWABAN & NILAI \\
\hline SELALU & 4 \\
\hline SERING & 3 \\
\hline KADANG-KADANG & 2 \\
\hline TIDAK PERNAH & 1 \\
\hline
\end{tabular}

(Sumber: Sugiyono, 2007: 93)

Instrumen penelitian menurut Sugiyono (2018: 102) adalah suatu alat yang digunakan mengukur fenomena alam maupun sosial yang diamati. Secara spesifik semua fenomena ini disebut variabel penelitian. Dalam kegiatan penelitian diperlukan alat untuk mengumpulkan data, alat tersebut yang dinamakan dengan instrumen. Dalam penelitian ini, peneliti menggunakan angket tertutup dengan check list yang terdapat pada pertanyaan-pertanyaan tentang evaluasi dalam pembelajaran Penjasorkes.

Tabel 2. Kisi-kisi uji coba Angket Evaluasi Dalam Pembelajaran Penjasorkes

\begin{tabular}{|c|c|c|c|c|}
\hline Variabel & Aspek & Indikator & $\begin{array}{c}\text { Nomor } \\
\text { Soal }\end{array}$ & Jumlah \\
\hline \multirow{11}{*}{$\begin{array}{l}\text { Pelaksanaan } \\
\text { Evaluasi } \\
\text { Dalam } \\
\text { Pembelajaran } \\
\text { Penjasorkes } \\
\text { di SMP } \\
\text { Negeri se- } \\
\text { Kecamatan } \\
\text { Belinyu }\end{array}$} & 1. $\begin{array}{l}\text { Persiapan } \\
\text { Mengajar }\end{array}$ & $\begin{array}{l}\text { Program } \\
\text { Mengajar }\end{array}$ & $\begin{array}{c}1,2,3 \\
4\end{array}$ & 4 \\
\hline & \multirow[t]{3}{*}{$\begin{array}{ll}\text { 2. } & \text { Pelaksanaan } \\
\text { Mengajar }\end{array}$} & $\begin{array}{l}\text { Penguasaan } \\
\text { Materi }\end{array}$ & $5,6,7$ & \multirow[t]{3}{*}{10} \\
\hline & & $\begin{array}{l}\text { Metode } \\
\text { Mengajar }\end{array}$ & $\begin{array}{c}8,9 \\
10,11\end{array}$ & \\
\hline & & $\begin{array}{c}\text { Penggunaan } \\
\text { Sarpras }\end{array}$ & $\begin{array}{c}12,13 \\
14\end{array}$ & \\
\hline & \multirow[t]{3}{*}{$\begin{array}{ll}\text { 3. } & \text { Evaluasi } \\
& \text { Pembelajaran }\end{array}$} & $\begin{array}{c}\text { Perencanaan } \\
\text { Evaluasi }\end{array}$ & $\begin{array}{c}15,16 \\
17\end{array}$ & \multirow[t]{3}{*}{16} \\
\hline & & $\begin{array}{c}\text { Pelaksanaan } \\
\text { Evaluasi }\end{array}$ & $\begin{array}{l}18,19, \\
20,21, \\
22,23\end{array}$ & \\
\hline & & $\begin{array}{l}\text { Syarat- } \\
\text { syarat } \\
\text { Evaluasi }\end{array}$ & $\begin{array}{l}24,25, \\
26,27, \\
28,29, \\
30\end{array}$ & \\
\hline & \multirow[t]{4}{*}{$\begin{array}{ll}\text { 4. } & \text { Prosedur } \\
& \text { Penilaian }\end{array}$} & $\begin{array}{l}\text { Pedoman } \\
\text { Penilaian }\end{array}$ & $\begin{array}{l}31,32, \\
33\end{array}$ & \multirow{4}{*}{16} \\
\hline & & $\begin{array}{c}\text { Sasaran atau } \\
\text { Objek } \\
\text { Penilaian }\end{array}$ & $\begin{array}{c}34,35 \\
36\end{array}$ & \\
\hline & & $\begin{array}{c}\text { Pengamatan } \\
\text { Daftar } \\
\text { Hadir }\end{array}$ & $\begin{array}{l}37,38, \\
39\end{array}$ & \\
\hline & & $\begin{array}{c}\text { Penilaian } \\
\text { Akhir }\end{array}$ & $\begin{array}{l}40,41, \\
42,43, \\
44,45\end{array}$ & \\
\hline
\end{tabular}

Analisis data hasil penelitian dapat dibedakan menjadi dua bagian yaitu analisi analisis kualitatif dan analisis kuantitatif. Perbedaan ini tergantung pada jumlah dan sifat data yang dikumpulkan. Jika data yang diperoleh bersifat uraian yang tidak dapat diubah kedalam bentuk-bentuk angka, maka analisi datanya menggunakan analisis data 
kualitatif. Sedangkan jika data yang dikumpulkan dapat diklasifikasikan dalam kategori-kategori atau diubah dalam bentuk angka-angka, maka analisis data kuantitatif cocok digunakan. Ibnu (dalam Winarno, 2013: 157).

\section{HASIL DAN PEMBAHASAN}

Dari hasil penelitian, pengolahan data terhadap aspek-aspek dan indikator-indikator dalam penelitian yang berjudul "Evaluasi Dalam Pembelajaran Penjasorkes di SMP Negeri se-Kecamatan Belinyu dengan menggunakan rumus DP $=\frac{n}{N} \times 100 \%$, dimana DP adalah tingkat keberhasilan yang dicapai, $\mathrm{n}$ adalah skor jawaban yang diperoleh dari responden dan $\mathrm{N}$ adalah skor jawaban maksimal atau ideal. Sebelum mencari tingkat keberhasilan yang dicapapai kita harus mencari N (skor jawaban maksimal) terlebih dahulu. Rumus mencari $\mathrm{N}$ adalah banyaknya skor yang ingin diteliti dikalikan banyaknya responden.

Besarnya persentase atau tingkat keberhasilan yang dicapai kemudian disesuaikan dengan kategori yang telah ditentukan sebagai berikut :

Tabel 3. Norma Penilaian

\begin{tabular}{|c|c|}
\hline INTERVAL & KATEGORI \\
\hline $81,25 \%-100 \%$ & SANGAT BAIK \\
\hline $62,49 \%-81,24 \%$ & BAIK \\
\hline $43,73 \%-62,48 \%$ & CUKUP BAIK \\
\hline $25,00 \%-43,72 \%$ & KURANG BAIK \\
\hline
\end{tabular}

(Sumber : Ibnu, 2010:59)

Berdasarkan hasil penelitian diperoleh hasil data sebagai berikut :

Tabel 4. Persentase pelaksanaan evaluasi dalam

\section{pembelajaran Penjasorkes di tiap-tiap} sekolah

\begin{tabular}{|c|c|c|}
\hline Sekolah & Persentase & Kategori \\
\hline SMPN 1 Belinyu & $83,88 \%$ & Sangat baik \\
\hline SMPN 2 Belinyu & $87,5 \%$ & Sangat baik \\
\hline SMPN 3 Belinyu & $73,75 \%$ & Baik \\
\hline SMPN 4 Belinyu & $89,16 \%$ & Sangat baik \\
\hline
\end{tabular}

Sumber : hasil olah data 2020

Untuk lebih jelasnya hasil persentase pelaksanaan evaluasi dalam pembelajaran Penjasorkes akan dijabarkan dalam bentuk diagram sebagai berikut :

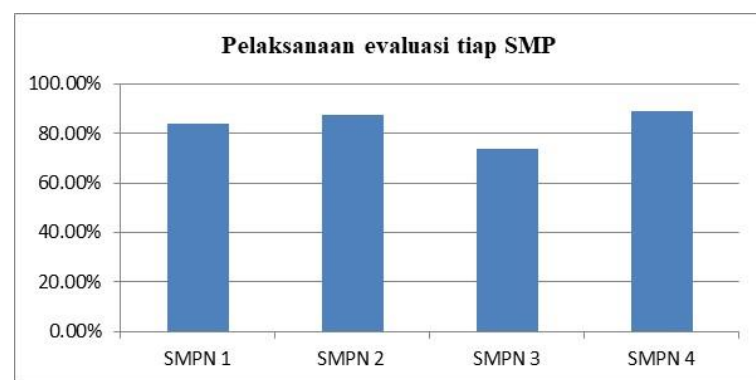

\section{Gambar 1. Diagram Evaluasi} Pembelajaran

Penjasorkes di tiap-tiap SMPN di kecamatan Belinyu

Berdasarkan hasil data diatas dapat kita lihat bahwa SMPN 4 Belinyu merupakan SMPN terbaik dalam proses pelaksanaan evaluasi pembelajaran Penjasorkes. SMPN 4 memiliki jumlah keseluruhan indikator 107 dengan persentase $89,16 \%$ dengan kategori sangat baik. Yang kedua SMPN 2 Belinyu memiliki jumlah keseluruhan indikator 210 dengan persentase $87,5 \%$ dengan kategori sangat baik. Yang ketiga SMPN 1 Belinyu memiliki jumlah keseluruhan indikator 302 dengan persentase $83,88 \%$ dengan kategori sangat baik. Dan yang terakhir SMPN 3 memiliki jumlah keseluruhan indikator 177 dengan persentase $73,75 \%$ dengan kategori baik. Jadi rata-rata proses pelaksanaan evaluasi dalam pembelajaran Penjasorkes sudah dilaksanakan dengan sangat baik.

Berikut hasil data penelitian dari masing-masing guru di SMPN se-Kecamatan Belinyu sebagai berikut :

\section{Tabel 5. Distribusi proses pelaksanaan} evaluasi dalam

pembelajaran Penjasorkes masing-masing

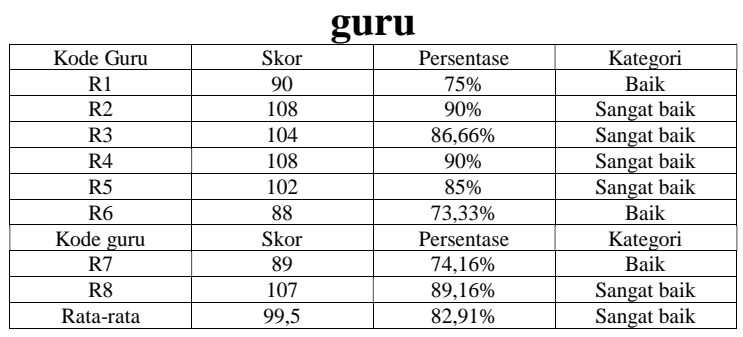

Sumber : hasil olah data 2020

Berikut diagram dari data diatas agar lebih jelas tentang proses pelaksanaan evaluasi dalam pembelajaran Penjasorkes di SMPN se-Kecamatan Belinyu : 


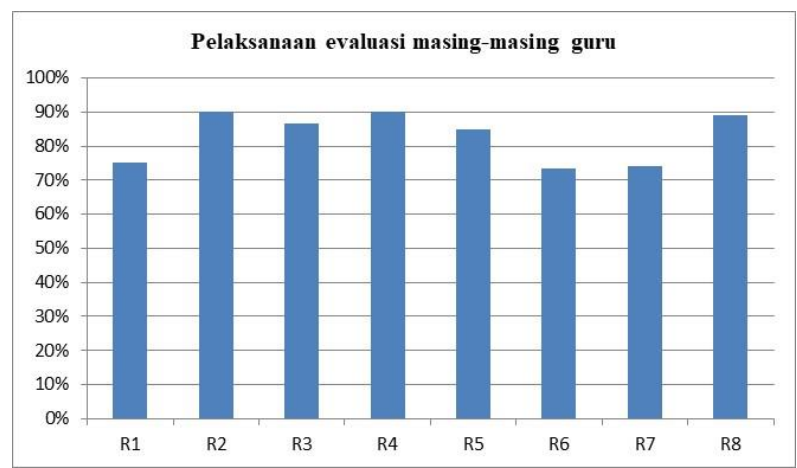

Gambar 2. Diagram proses pelaksanaan evaluasi masing-masing guru SMPN se-Kecamatan Belinyu

Berdasarkan data diatas dapat dilhat bahwa persentase tertinggi sebanyak $90 \%$ dan yang terendah sebanyak $73,33 \% .5$ orang guru memiliki kategori pelaksaanan evaluasi sangat baik yaitu R2 dan R4 dengan persentase $90 \%, \mathrm{R} 3$ dengan persentase $86,66 \%, \mathrm{R} 5$ dengan persentase $85 \%$, R8 dengan persentase $89,16 \%$. Sedangkan 3 orang memiliki kategori baik yaitu R1 dengan persentase $75 \%$, R6 dengan persentase $73,33 \%$ dan R7 dengan persentase $74,16 \%$. Dari data diatas dapat disimpulkan bahwa proses pelaksanaan evaluasi dalam pembelajaran Penjasorkes di SMPN se-Kecamatan Belinyu rata-rata sudah dilaksanakan dengan sangat baik.

Tabel 6. Distribusi pelaksanaan evaluasi dari tiap-tiap aspek evaluasi

\begin{tabular}{|c|c|c|c|}
\hline No & Aspek Evaluasi & Persentase & Kategori \\
\hline 1 & Persiapan mengajar & $85,41 \%$ & Sangat baik \\
\hline 2 & Pelaksanaan mengajar & $79,46 \%$ & Baik \\
\hline 3 & Evaluasi pembelajaran & $83,68 \%$ & Sangat baik \\
\hline 4 & Prosedur penilaian & $83,80 \%$ & Sangat baik \\
\hline
\end{tabular}

Sumber : Hasil olah data 2020

Untuk lebih jelasnya data tentang aspek evaluasi yang diamati dapat digambarkan dalam bentuk diagram sebagai berikut :

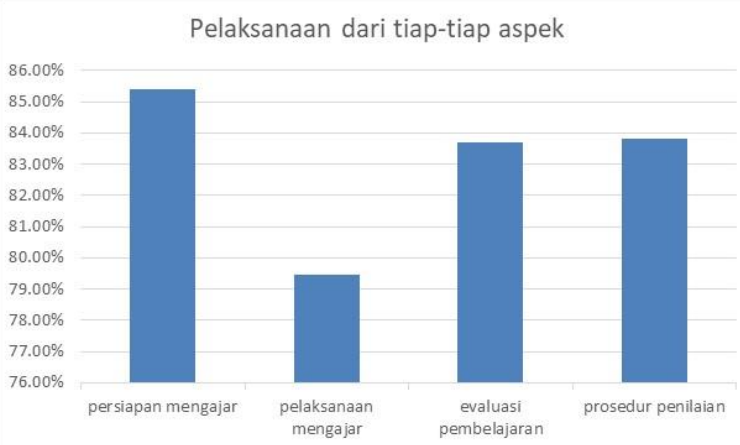

Gambar 3. Diagram persentase pelaksanaan dari tiap-tiap aspek evaluasi di SMPN se-Kecamatan Belinyu
Dari diagram diatas dapat dilihat pesentase tertinggi dari aspek evaluasi yang diamati adalah aspek persiapan mengajar dengan persentase $85,41 \%$, disusul aspek prosedur penilaian dengan persentase $83,80 \%$, aspek evaluasi pembelajaran dengan persentase $83,68 \%$ dan yang terendah aspek pelaksanaan mengajar dengan persentase $79,46 \%$.

Berikut hasil data penelitian dari soalsoal dari tiap indikator evaluasi di SMPN seKecamatan Belinyu.

\section{Tabel 7. Distribusi pelaksanaan evaluasi dari soal-soal}

dari tiap-tiap indikator evaluasi di SMPN

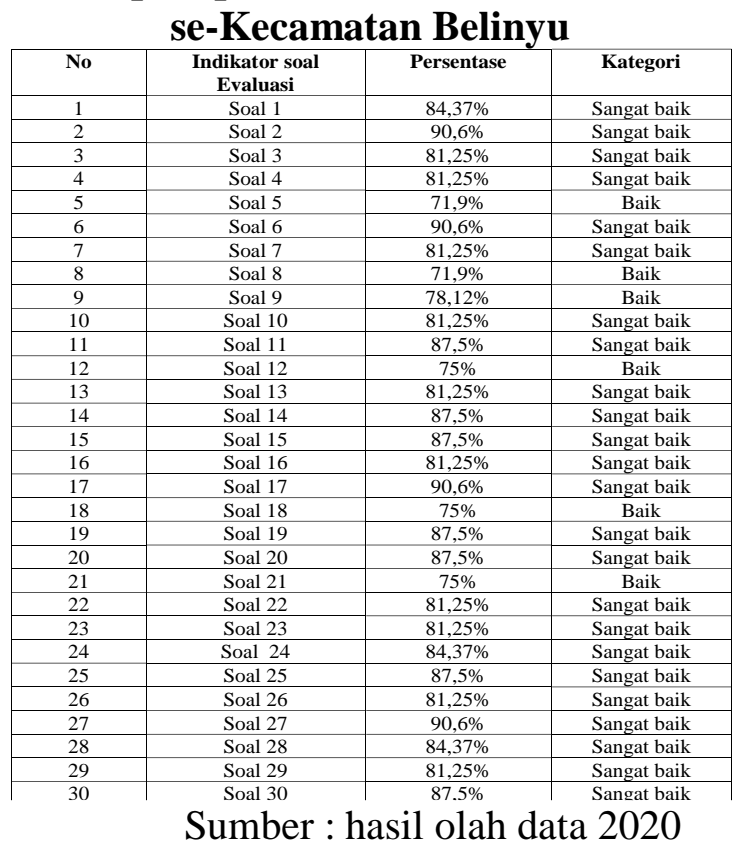

Dari tabel diatas terdapat 6 sub indikator yang menunjukkan predikat baik dan 24 sub indikator yang menunjukkan predikat sangat baik.

Hasil yang diperoleh dari hasil penelitian dari evaluasi dalam pembelajaran Penjasorkes di SMP Negeri se-Kecamatan Belinyu adalah sebagai berikut :

Tabel 8. Hasil evaluasi dalam pembelajaran Penjasorkes di SMP Negeri se-Kecamatan Belinyu

\begin{tabular}{|c|c|c|c|c|}
\hline $\mathbf{X}$ & Interval & Kategori & Frekuensi & Persentase \\
\hline 1 & $81,25 \%-100 \%$ & Sangat baik & 95 & $39,74 \%$ \\
\hline 2 & $62,49 \%-81,24 \%$ & Baik & 125 & $52,30 \%$ \\
\hline 3 & $43,73 \%-62,48 \%$ & Cukup baik & 19 & $7,94 \%$ \\
\hline 4 & $25,00 \%-43,72 \%$ & Kurang baik & 0 & 0 \\
\hline
\end{tabular}

Sumber : hasil olah data 2020 
Berdasarkan hasil tabel diatas dapat diketahui bahwa evaluasi dalam pembelajaran penjasorkes di SMP Negeri se-Kecamatan Belinyu yang terdiri dari aspek persiapan mengajar, pelaksanaan mengajar, evaluasi pembelajaran dan prosedur penilaian sudah dilaksanakan dengan baik. Dari 8 responden dengan 45 pertanyaan, yang dijawab dengan sangat baik berjumlah 95 jawaban dengan persentase $39,74 \%$, yang menjawab dengan baik berjumlah 125 jawaban dengan persentase $52,30 \%$, yang menjawab dengan cukup baik berjumlah 19 jawaban dengan persentase $7,94 \%$ dan tidak ada yang menjawab jawaban kurang baik. Jadi total persentase keseluruhan dari evaluasi dalam pembelajaran di SMP Negeri se-Kecamatan Belinyu adalah 99,98\% dengan kategori sangat baik.

Persamaan dan perbedaan hasil penelitian ini dengan hasil penelitian kajian terdahulu yang relevan adalah sebagai berikut

Tabel 9. persamaan hasil penelitian ini dengan hasil penelitian terdahulu yang relevan

\begin{tabular}{|l|l|c}
\hline \multicolumn{1}{|c|}{ Panuntun } & \multicolumn{1}{|c|}{ Hermawan } & \multicolumn{1}{c}{ Sutikno } \\
\hline $\begin{array}{l}\text { Didalam aspeknya terdapat aspek } \\
\text { persiapan mengajar }\end{array}$ & $\begin{array}{l}\text { Memiliki 3 responden yang } \\
\text { memiliki persentase kategori } \\
\text { baik }\end{array}$ & $\begin{array}{l}\text { Memiliki persamaan pada } \\
\text { indikator evaluasi }\end{array}$ \\
\hline $\begin{array}{l}\text { Objek yang diteliti yaitu evaluasi } \\
\text { dalam penjasorkes di SMP }\end{array}$ & $\begin{array}{l}\text { Sama sama menggunakan } \\
\text { isntrumen angket tertutup }\end{array}$ & \\
\hline $\begin{array}{l}\text { Variabelnya mengukur tentang } \\
\text { proses pelaksanaan evaluasi } \\
\text { dalam pembelajaran penjasorkes }\end{array}$ & & \\
\hline
\end{tabular}

Tabel 10. perbedaan hasil penelitian ini dengan hasil penelitian terdahulu yang relevan

\begin{tabular}{|c|c|c|}
\hline Panuntun & Hermawan & Sutikno \\
\hline $\begin{array}{l}\text { Pada penelitian ini, aspek persiapan } \\
\text { mengajar memliki kategori sangat } \\
\text { baik sedangkan panuntun aspek } \\
\text { persiapan mengajarnya memiliki } \\
\text { kategori baik saja }\end{array}$ & $\begin{array}{l}\text { Pada penelitian hermawan, } \\
\text { responden yang memilki kategori } \\
\text { sangat kurang }(1 \text { responden), } \\
\text { kategori ( } 7 \text { responden), kategori } \\
\text { cukup (11 responden), kategori } \\
\text { baik (3 responden) dan kategori } \\
\text { sangat baik ( } 2 \text { responden) } \\
\text { sedangkan penelitian ini yang } \\
\text { memiliki kategori baik (3 } \\
\text { responden) dan kategori sangat } \\
\text { baik (5 responden) }\end{array}$ & 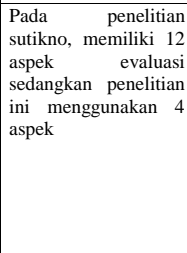 \\
\hline $\begin{array}{l}\text { Penelitian ini memiliki } 4 \text { aspek } \\
\text { sedangkan panuntun memiliki } 9 \\
\text { aspek evaluasi }\end{array}$ & $\begin{array}{l}\text { Penelitian hermawan } \\
\text { menggunakan banyak responden } \\
\text { yaitu } 32 \text { responden sedangkan } \\
\text { penelitian ini menggunakan } 8 \\
\text { responden }\end{array}$ & 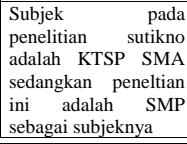 \\
\hline Panuntun & Hermawan & Sutikno \\
\hline $\begin{array}{l}\text { Teknik analisis data oleh } \\
\text { panuntun menggunakan statistic } \\
\text { deskriptif sedangkan penelitian } \\
\text { ini menggunakan deskriptif } \\
\text { persentase }\end{array}$ & $\begin{array}{l}\text { Penelitian hermawan } \\
\text { menggunakan analisis deskriptif } \\
\text { kuantitatif dan subjeknya adalah } \\
\text { SD sedangkan penelitian ini } \\
\text { menggunakan analisis deskriptif } \\
\text { kualitatif dan subjeknya adalah } \\
\text { SMP }\end{array}$ & \\
\hline
\end{tabular}

\section{KESIMPULAN}

Berdasarkan hasil penelitian yang telah dilakukan, maka dapat ditarik kesimpulan sebagai berikut :

1. Pelaksanaan evaluasi dalam pembelajaran penjasorkes di SMP Negeri seKecamatan Belinyu pada masing-masing sekolah sudah termasuk dalam kategori sangat baik.

2. Pelaksanaan evaluasi dalam pembelajaran penjasorkes di SMP Negeri seKecamatan Belinyu pada masing-masig guru atau responden sudah termasuk dalam kategori sangat baik.

3. Pelaksanaan evaluasi dalam pembelajaran penjasorkes di SMP Negeri seKecamatan Belinyu pada tiap-tiap aspek evaluasi rata-rata sudah termasuk dalam kategori sangat baik.

4. Pelaksanaan evaluasi dalam pembelajaran penjasorkes di SMP Negeri seKecamatan Belinyu pada soal-soal tiap indikator rata-rata sudah termasuk dalam kategori sangat baik.

5. Rincian dari aspek evaluasi dalam pembelajaran penjasorkes di SMP Negeri se-Kecamatan Belinyu adalah 4 dari aspek yang diujikan 1 diantaranya berkategori baik dan 3 adalah berkategori sangat baik.

\section{DAFTAR PUSTAKA}

Arikunto, S. (2007). Prosedur Penelitian Suatu Pendekatan Praktik. Jakarta: Rineka Cipta.

Asrul, Rusydi Ananda, dan Rosnita. (2015). Evaluasi Pembelajaran. Medan: Citapustaka Media

Depdiknas. (2006). Kurikulum Pendidikan Jasmani. Jakarta: Depdiknas.

Hamalik, O. (2006). Proses Belajar Mengajar. Jakarta: PT. Bumi Aksara.

Hermawan, Adhi Oktavian. 2018. Pelaksanaan Evaluasi Dalam Pembelajaran Penjasorkes di SD Negeri se-Kecamatan Pedan Kabupaten Klaten. SkripsiS-1, Jurusan Pendidikan Guru Sekolah Dasar Penjas Pendidikan Olahraga Universitas Negeri Yogyakarta. 
Ngatman. (2017). Evaluasi Pendidikan Jasmani, Olahraga dan Kesehatan. Jawa Tengah: CV Sarnu Untung.

Panuntun, Adji Bagus. 2010. Survei Proses Pelaksanaan Evaluasi Penjasorkes di SMP Negeri se-Kecamatan Ungaran Barat dan Ungaran Timur. SkripsiS-1, Jurusan Pendidikan Jasmani Kesehatan Dan Rekreasi Universitas Negeri Semarang.

Sutikno, Ibnu. 2010. Survei Pelaksanaan Evaluasi Hasil Belajar Pendidikan Jasmani Olahraga dan Kesehatan Berdasarkan KTSP SMA se-Kota Tegal. SkripsiS-1, Jurusan Pendidikan Jasmani Kesehatan Dan Rekreasi Universitas Negeri Semarang.

Rosdiani, D. (2015). Kurikulum Pendidikan Jasmani. Bandung: Alfabeta.

Siyoto, S. (2015). Dasar Metodologi Penelitian. Sleman: Literasi Media Publishing.

Sugandi, A. (2006). Teori Pembelajaran. Semarang: UNS PRESS.

Sugiyono. (2007). Metode Penelitian Kuantitatif, Kualitatif dan $R \& D$. Bandung: Alfabeta.

Sugiyono. (2008). Metode Penelitian Kuantitatif, Kualitatif dan $R \& D$. Bandung: Alfabeta.

Sugiyono. (2018). Metodologi Penelitian Kuantitatif, Kualitatif dan $R \& D$. Bandung: Alfabeta.

Widiyanto, J. (2018). Evaluasi Pembelajaran. Madiun: UNIPMA PRESS.

Winarno. (2004). Evaluasi Dalam Pendidikan Jasmani dan Olahraga. Jakarta: Center For Human Capacity Development.

Winarno. (2006). Persfektif Pendidikan Jasmani dan Olahraga. Malang: Laboratorium Jurusan Ilmu Keolahragaan FKIP Universitas Negeri Malang.

Winarno. (2013). Metologi Penelitian Dalam Pendidikan Jasmani. Malang: Universitas Negeri Malang (UMS PRESS).

Winarno. (2014). Evaluasi Hasil Belajar Pendidikan Jasmani Olahraga dan Kesehatan. Malang: Universitas Negeri Malang. 